\title{
A Review of Open Educational Resources in the Geosciences: Guidelines and Criteria
}

\section{Authors:}

Samantha Teplitzky*, Open Science Librarian, Earth Sciences \& Map Library, University of California, Berkeley, 50 McCone Hall, Berkeley, CA 94720, steplitz@berkeley.edu, ORCID: 0000-0001-7071-332X

Shaun Hardy, Librarian, Earth \& Planets Laboratory, Carnegie Institution for Science, Washington, DC 20015, shardy@carnegiescience.edu, ORCID: 0000-0002-7259-3330

Kay Johnson, Head of Collection and Technical Services, Radford University, 801 E. Main St., Radford, VA 24142-6881, kjohnson497@radford.edu, ORCID: 0000-0001-6472-345X

Robert Tolliver, Sciences Librarian, North Dakota State University, Fargo, ND 58108-6050, robert.tolliver@ndsu.edu, ORCID: 0000-0003-1584-433X

Lori Tschirhart, Assistant Director, STEM, University of Michigan Library, Ann Arbor, MI 48109-1190, Itz@umich.edu, ORCID: 0000-0001-9322-3171

Ifigenia Vardakosta, Phd. Head Librarian, Harokopio University, Library \& Information Centre, Athens, Greece, ifigenia@hua.gr, ORCID: 0000-0001-9465-8476

${ }^{*}$ Corresponding author

This is a non-peer reviewed preprint submitted to EarthArXiv.

Subsequent versions of this manuscript may have different content. We welcome feedback. Please contact Sam Teplitzky (steplitz@berkeley.edu) regarding this manuscript's content. 


\section{A Review of Open Educational Resources in the Geosciences: Guidelines and Criteria}

\section{Authors:}

Samantha Teplitzky*, Open Science Librarian, Earth Sciences \& Map Library, University of California, Berkeley, 50 McCone Hall, Berkeley, CA 94720, steplitz@berkeley.edu, ORCID: 0000-0001-7071-332X

Shaun Hardy, Librarian, Earth \& Planets Laboratory, Carnegie Institution for Science, Washington, DC 20015, shardy@carnegiescience.edu, ORCID: 0000-0002-7259-3330

Kay Johnson, Head of Collection and Technical Services, Radford University, $801 \mathrm{E}$. Main St., Radford, VA 24142-6881, kjohnson497@radford.edu, ORCID: 0000-0001-6472-345X

Robert Tolliver, Sciences Librarian, North Dakota State University, Fargo, ND 58108-6050, robert.tolliver@ndsu.edu, ORCID: 0000-0003-1584-433X

Lori Tschirhart, Assistant Director, STEM, University of Michigan Library, Ann Arbor, MI 48109-1190, Itz@umich.edu, ORCID: 0000-0001-9322-3171

Ifigenia Vardakosta, Phd. Head Librarian, Harokopio University, Library \& Information Centre, Athens, Greece, ifigenia@hua.gr, ORCID: 0000-0001-9465-8476

${ }^{*}$ Corresponding author

Keywords:

Open Educational Resources, OER, Geoscience Education, Open Textbooks

\section{Abstract}

Open Educational Resources (OER) offer a link between new trends in learning and instruction, and the promise of transparency and inclusion offered by open science practices. Open textbooks, virtual field and laboratory experiences, interactive computational environments, and openly licensed media are among the many types of OER in use today. Adoption of subject-specific OER has the potential to replace expensive textbooks with free alternatives that can be adapted and reused. While globally, instructors in all scientific disciplines are becoming familiar with OER, geoscientists in particular have been slow to utilize these resources.

This study examines the creation and adoption of OER in the geosciences with a goal of providing guidance for institutions, libraries and librarians who support and fund OER initiatives. Beginning with a review of student and faculty perceptions and awareness regarding OER, the study expands to consider OER availability in STEM overall. Furthermore, the creation and adoption of OER in geosciences is discussed. An environmental scan, employed to identify and characterize available college-level OER in this discipline, provided a baseline for the study. Analysis of the scan along with a review of OER, textbook and field guide standards informs a new set of proposed guidelines for geoscience OER. This work will describe these guidelines and offer a call for community feedback. 
Several of the guidelines are applicable to STEM fields in general, but we also propose specific aspirational criteria unique to geoscience instructional settings. The study is a starting point for authors and adopters to create OER that are discoverable, accessible, authoritative, shareable and sustainable. OER also double as research objects, offering an entry point into understanding student engagement and providing a path to welcome and include a diverse set of students into the study of geoscience.

\section{Introduction}

One of the traditional tasks for libraries and librarians is to facilitate unrestricted and free access to learning materials, which speaks to the potential role of libraries in the support and promotion of Open Educational Resources (OER). The wide impact of the open science and open access movements established new roles, tasks and procedures for libraries and librarians, helping them fulfill their mission. Additionally, the COVID-19 pandemic has exacerbated the needs of both students and teachers for Online Educational Resources. Libraries around the globe, as well as other organizations and associations have responded to those needs in various ways.

Several international statements and initiatives reflect the growing importance of OER around the globe. UNESCO promoted OER to its members with a published recommendation in 2019 (Recommendation on Open Educational Resources (OER), 2019). Similarly, IFLA has provided input to this work issuing a brief on OER which builds on the recent UNESCO recommendation (IFLA -- IFLA Responds to Consultation on Open Educational Resources, 2018; IFLA, 2019). LIBER recently started a new Working Group on Educational Resources in support of European librarians in their role to provide educational resources, both open and online (Call for Members - NEW LIBER Working Group on Educational Resources, 2021). OECD's study entitled "Giving knowledge for free: the emergence of free educational resources" examines, among others, issues relating to better access to OER such as quality management, translation and localization of content, and improved web access for disabled people. It also examines the use of open source software, increasing interoperability and emerging technologies (OECD, 2007, p. 99). In the United States, the Association of College \& Research Libraries (ACRL) designed traveling RoadShow workshops entitled OER \& Affordability to help academic library professionals understand the basics of OER and how libraries can be involved in affordability initiatives at their institutions (Blicher et al., 2021). Funders, institutions and libraries are key in supporting, promoting and preserving these works.

OER have the potential to replace expensive textbooks with free alternatives that can be adapted and reused. OER are often cited for their cost savings potential, but the technological advantages are particularly applicable to the geosciences. The benefits of interactive features that allow for computational exploration, laboratory simulations, and virtual field trips are particularly relevant as we emerge from the COVID-19 year of remote learning. In addition, OER hold promise as a means of welcoming students who are historically underrepresented in the field. Despite these benefits, the discipline has been slow to adopt them.

In this study we examine the current availability of OER for college- and university-level geoscience courses and make recommendations for a set of standards to guide authors as they create, adapt and adopt OER for their courses. Our environmental scan located about 70 OER that cover Earth or geoscience topics, 40 of which are textbooks or laboratory manuals. A range 
of platforms and software was employed but the most common set up involved a locally hosted instance of the Pressbooks software.

After analyzing current OER, we created a set of guidelines that we hope will encourage wider adoption and easier discovery of these works. Guidelines focus specifically on eight themes--Purpose; Authority; Discoverability; Diversity, Equity, Inclusion, Accessibility; Features; Visuals/Geospatial; Terms and Licensing; and Privacy. Within those themes, particular components and examples are identified to standardize how OER are created and published.

This work is an initial study of the state of OER in geoscience as well as a call for standard features that we feel will propel their use and adoption. While it is beyond the immediate scope of this work, future accounts will consider the labor and funding required to create and sustain these works, as well as the process of formalizing credit as a component of tenure and promotion criteria.

\section{Literature Review}

The large body of literature on OER in higher education may be categorized in the COUP Framework into studies of Cost, Outcomes, Usage, and Perceptions (Open Education Group, n.d.). Cost studies frequently point to the large numbers of students who forgo purchasing (and reading) assigned textbooks, often because of the associated costs. Basken (2020) reported that US college students pay on average \$1,240 per year on textbooks and supplies. Kristof (2018) reported that $65 \%$ of students have skipped buying required textbooks at some point in their college career. Allen (N. Allen, 2018) documented the financial savings realized through OER adoption. Cost savings are particularly relevant in science fields given the generally high cost of textbooks. Fisher (2018), surveying students in biology classes, found that the students would save an average of $\$ 81$ on their textbooks. Students also indicated that they would be more likely to choose a section with an open textbook over one with a traditional textbook.

While the number of open textbooks available remains modest - the Open Textbook Library currently lists 1012 titles, including 134 in the natural sciences (Biology, Chemistry, Earth Sciences, and Physics) - adoption of OER shows strong growth. According to the Open Syllabus Project, in 2017 roughly 1 in 300 classes in US institutions used an open textbook and 1 in 400 used Open Access monographs (Karaganis, 2020). The non-profit publisher OpenStax estimated that more than half of U.S. colleges use at least one of their three dozen OER titles (Koenig, 2019). For comparison, Pearson, largest commercial provider of college textbooks in the U.S., currently offers 1,500 titles in the American market alone (Camera, 2019).

\section{International initiatives and the role of libraries}

OER initiatives are emerging around the world. In Australia, the National Centre of Student Equity in Higher Education was funded by Deakin University to undertake a national scoping study looking at the potential of open textbooks to remedy injustice across three dimensions: economic, identity and representation. They are demonstrating that free textbooks not only save money for diverse students, but also ensure that diverse students can recognize themselves 
inside their textbooks (The Project Begins! - Australian Open Textbooks as Social Justice, 2019).

OER Africa was established in 2008 with a vision to support the emergence of African education systems and institutions that play a critical role in building and sustaining African societies and economies through free, open development and sharing of common intellectual capital. OER Africa is "undertaking collaborative work to develop the professional competences and skills of stakeholders within African higher education institutions so that they can implement OER practices to improve the quality of teaching and learning" (https://www.oerafrica.org/). In most countries of Asia, interest in and the production, distribution, and use of OER are still very much in the early stages of development, nevertheless OER's potential value to improve the quality of curriculum, content and instruction, facilitate academic collaboration and enhance equitable access to knowledge resources cannot be overstated (Dhanarajan \& Porter, 2013, p.17).

The potential for OER in higher education has globally led institutions, organizations, and universities to take various actions and take advantage of funded projects (e.g. project "Kallipos" in Greece, https://www.kallipos.gr/en/; ROER4D at the University of Cape Town, South Africa, http://www.roer4d.uct.ac.za/). Collaborative initiatives, such as those in Spain (Hermosa, 2020), have enabled libraries to play a role in facilitating faculty understanding of OER. The European Commission launched the OpenEdu Framework to develop and promote a common understanding of open education to make OER easily adaptable for learners, teachers, researchers and administrators (Open Education - OpenEdu Framework, 2016).

\section{OER Awareness and Perceptions}

Many studies have investigated student and faculty awareness and perceptions of OER in the United States (Hilton, 2016; Pitt, 2015) and Canada (Jhangiani \& Jhangiani, 2017). Awareness of OER has increased markedly in the past ten years. While chief academic officers at a majority of institutions were already "aware" or "very aware" of OER a decade ago, two-thirds to three-quarters of faculty members were not aware of OER at the time (I. E. Allen \& Seaman, 2012 , 2014). By 2018-19, for the first time, the percentage of faculty claiming to be at least "somewhat aware" of OER exceeded $50 \%$. The percentage of faculty claiming to be "aware" or "very aware" has risen steadily from $20 \%$ in $2014-15$ to $42 \%$ in $2019-2020$ (Seaman \& Seaman, 2020).

For educators, the adoption of OER puts ownership of curriculum directly back into their hands, both encouraging them to reflect on how the materials might be redesigned and improved, and empowering them to make these improvements directly (Robinson et al., 2014) as their open licenses permit them to modify or integrate the material with other resources (Pitt, 2015). High quality OER are also thought to have a pedagogical benefit as they allow for all students to access the same version of the same course content on the first day of the class. However, educators also report increased class preparation times when using OER (Bliss et al., 2013). This may be due to educators' desire to remix and customize OER content, and may indicate a need for stable funding to create and sustain these projects. Several studies mention the use of institutional grants to launch projects (Liu et al., 2021; Bentley et al., 2020; Mengason, 2020; Karamperidou et al., 2019; Musser, 2017), but less is written about the 
longevity of open educational resources and related funding needs. Liu et al. (2021) however focuses on instructional design and describes a multi-year iterative process which incorporates student feedback and user experience testing.

For students, the main advantages of the OER appear to be financial benefits without any decrease in their learning outcomes (Fischer et al., 2015). In educational settings where tuition costs are based directly on the number credits taken, funds saved on textbooks permits students to enroll in additional courses (Jhangiani \& Jhangiani, 2017; Fischer et al., 2015). The majority of students believe OER to be comparable in quality to traditional textbooks (Hilton, 2016). Conveniences like immediate access, portability (not having to carry around heavy backpacks), and permanent ownership, as well as the ability to share the resource with others favors the use of OER from students' point of view (Jhangiani \& Jhangiani, 2017; Robinson et al., 2014).

\section{OER in STEM}

Interest and availability of OER vary across science disciplines according to the availability of suitable OER for the subject area or the nature of instruction within a discipline. Farrow, Pitt, and Weller (2020) shared data on the adoption of OpenStax textbooks in the UK Open Textbook Project and found adoption across many science disciplines with the highest levels in Physics, Biology, and Anatomy \& Physiology respectively. Most current OER are structured like traditional, commercial textbooks and focus on high-enrollment, introductory level courses, such as Biology, Chemistry, Physics and Algebra. Fewer comprehensive course OER have been created for lower enrollment subjects, such as Physical Geology, as well as upper-level courses. Arnaud (2019) found that LibreTexts and OpenStax had few options for upper-level chemistry courses.

An important consideration in adopting OER in science is the impact of using OER versus standard textbooks on student performance. Recent studies in the sciences have found that student performance using OER does not differ from the same courses being taught with traditional, commercial textbooks. Allen (G. Allen et al., 2015) looked at the class performance of students in general chemistry, comparing the performance of students in sections using the OER ChemWiki with students in sections using the traditional textbook. They found no significant difference in performance between the sections using ChemWiki versus the traditional textbook, indicating that the OER was a viable alternative resource. Mathew and Kashyap (2019) also found no statistically significant difference in final course grades for students in an introductory astronomy course comparing students in a class using a traditional textbook and students during the following academic year using an OER textbook while keeping all assignments and performance measures the same. In another recent study (Sansom et al., 2021), students were given the option to use a commercial textbook or an OER textbook in a general chemistry class. Again, the results did not show any significant difference in performance between students using either textbook.

Benefits to student performance were more evident for interactive OER or thematic modules. Several studies test the effectiveness of themed modules or topics within the geosciences (Gilbert et al., 2019; McNeal et al., 2014, 2020) and report on increased student engagement and achieved learning goals. While modeling student engagement specifically with 
interactive digital textbooks, like those built upon Jupyter Notebooks, Smith et al. (2021) found that active interaction was significantly more effective than reading time in predicting student performance. Students reported a preference for interactive works that enabled them to step through concepts by manipulating example code, visualizations, and other interactive elements.

\section{OER in Geoscience}

Geoscience as a discipline offers unique opportunities to apply OER. Early work such as (Kobluk, 1993) referenced the ease of updating computer-generated historical geology texts, and more collaborative, grassroots projects like DLESE (Digital Library of Earth System Education), launched in 1999, highlight the long-standing community interest in the sharing and reuse of educational outputs (Kastens, 2005; Marlino et al., 2001). The creation and adoption of OER in geoscience is more often discussed in conference presentations, rather than peer-reviewed literature, but common themes emerge that are particularly relevant: application of remote and virtual learning to field and lab work; advances in software and computation that allow for easier sharing and adaptation; and the importance of interactive experiences that engage students, and welcome students that are historically underrepresented in the field.

Geoscience's fieldwork and lab experiences are well-suited for replication in OER which may take the form of online modules, videos, interactive tutorials and code, beyond what is possible in conventional texts. Pitts and Bentley (2015) note that virtual field guides give "students the opportunity to investigate field sites which they might be physically unable to visit and also allow educators the ability to instantly access distant field sites as teaching areas." Klippel et al. (2019) upholds the importance of immersive experiences as reliable substitutes for in person visits as well. Several studies (Brady, 2020; Hendricks, 2018; E. A. Johnson et al., 2018) discuss the use of OER to create virtual, interactive laboratory experiences that allow students to interact with and visualize rock and fossil samples with increased flexibility and without concerns related to laboratory safety.

The ability to create, version, share, and reuse these materials is key to their success. The opengeology.org platform allows for easy versioning (C. Johnson et al., 2017, p. 201) while material hosted on the geoscience portion of LibreTexts is interactive and reconfigurable (Omta \& Larsen, 2018). Recent projects like ClimLab (Rose, 2019; Rose, 2018) and Earth Analytics (Wasser et al., 2019) take this a step farther using interactive, reproducible computational code in executable environmentals like a Jupyter Notebook and offering materials in publicly available GitHub repositories.

The importance of diversity and recruitment is considered a potential benefit of OER in geoscience. Bentley et al. (2020) note the inclusion of diverse scientists as examples within their historical geology text, and Bush \& Mattox (2020) review texts in physical geology to assess progress in gender and racial representation over a ten year period. Publisher-led initiatives addressing the lack of diversity and equity in textbooks are gradually appearing. OER provider OpenStax identified several areas where the lack of diversity and equity in textbooks is reflected - the examples and illustrations provided, the use of inappropriate terminology, the presence or absence of specific topics or issues, and the balance between topics (Palmiotto and Swift, 2019). In 2021 mega-publisher Pearson released extensive guidelines for its authors and editors aimed at promoting diversity and avoiding negative stereotypes in its textbooks 
(McKenzie, 2021). On a related note, Mengason (2020) suggests that interactive texts allow for hands-on analytical work which makes lower division introductory coursework more engaging, aid as a recruitment tool in geoscience. Karamperidou et al. (2019) lists student contributions to text as a positive means of engagement and Musser (2017) relates that some institutions have leveraged the availability of OER to improve recruitment. International initiatives have further potential to contribute to this goal.

\section{Standards and Guidelines}

We searched the education and geoscience literature that discussed any general OER standards or evaluation guidelines that have been established or promoted. Scant information was found that addressed OER standards specifically for post-secondary geoscience or STEM OER, so we also searched more broadly for literature that considered the evaluation of post-secondary textbook selection and discussed the evaluation of OER for postsecondary educational purposes more broadly. Across the literature, several articles and OER selection resources such as LibGuides and one page handouts addressed certain aspects of OER standards appropriate for general post-secondary STEM education. Broad concepts like authority, purpose, adaptability, and readability were mentioned in numerous places. However, we did not find a resource that addressed all criteria holistically. Jung et al. (2016) summarizes how unclear licensing information and user uncertainty regarding the appropriateness of content, design, ease of use and pedagogical standards may be reasons for low OER uptake. Jung lists the following five selection criteria that are most critical to increasing the adoption of OER:

1. The OER accords with open content licenses (e.g., Creative Commons License) and is properly attributed.

2. The OER can be easily reused, revised, remixed and shared with other materials to meet particular teaching/learning needs.

3. The goals and purposes of the OER are easily understood.

4. The content is accurate and up to date.

5. The content covers educationally significant concepts and leads to deep understanding.

We also considered what additional criteria might be appropriate for post-secondary OER for geoscience. We hoped to find guidance about evaluating images for quality or adaptability, the presence of georeferenced objects, and attention to geoscience nomenclature. Though we did not find any literature addressing these concepts specifically, the literature did present a compelling suggestion for incorporating robust peer review into the evaluation of digital educational resources (Gold et al., 2012). The paper presents a model for peer review of digital earth science resources and examines the differences between how print and digital textbooks are adopted. The paper also proposes the production of curated OER instructional materials to facilitate evaluation.

Early studies such as Christman et al. (1985) compared faculty and student evaluations of geology textbooks. Students focused on interest level, ease of reading and ease of understanding the books whereas faculty noted accuracy, completeness and currency. Kortz et 
al. (2017) offered more practical suggestions to reduce cognitive load among novice learners in introductory geology courses, and recommended integrating text and figures and minimizing extraneous geologic vocabulary. Their recommendations apply to printed textbooks, but could be extended effectively to OER as well.

These studies form the basis of potential OER criteria in the geosciences, but also revealed a need for substantive standards and guidelines for the creation and evaluation of geoscience OER.

\section{Methods}

In January 2021, we completed an environmental scan of available OER that cover Earth science or geoscience topics. We began our process by searching known OER aggregator sites (listed on the Geoscience Information Society's "Open Textbooks" page, http://www.geoinfo.org/open-textbooks), library licensed databases, the Directory of Open Access Books (DOAB), Opensyllabus, local courses at our own universities, as well as abstracts for the Geological Society of America (GSA) and American Geophysical Union (AGU) annual conferences. Our initial approach cast a wide net and located 70 open resources of various types including videos, course content, lab and field manuals, computational handbooks as well as traditional textbooks. We identified 31 examples of course-related materials including videos, syllabi, course websites, lecture notes and homework, but ultimately decided that this material was out of scope. Of the remaining titles, there were 40 textbooks and laboratory manuals.

Full results of the scan can be found in Appendix 1 at this link:

https://doi.org/10.5281/zenodo.5542323

\section{Results}

\section{Environmental Scan}

Texts were primarily aimed at undergraduate audiences and spanned a variety of core subjects including basic geology, geochemistry, atmospheric science, petrology, mineralogy, structural geology, oceanography, seismology, as well as computational methods specific to the geosciences.

The texts are split between those developed for a particular university course, and perhaps not adopted beyond that setting, and those designed for more general audiences. Unlike library-subscribed or licensed resources, there is no clear way to determine the usage of many of these texts. Some platforms report the number of related PDF downloads or citations of the works, but not all, and downloads do not correlate with individual course adoption. The OER metrics hosted on Opensyllabus give some indication of the adoption of these titles in courses at different institutions. ${ }^{1}$ The top 10 titles are shown in Table 1, but likely represent a limited

\footnotetext{
${ }^{1}$ https://oer.opensyllabus.org/?category=Top \%20Titles\&field names=Earth\%20Sciences\&;
} accessed on June 17, 2021 
sample of institutions where earth science or geoscience majors are offered and syllabi are publicly available.

\begin{tabular}{|l|l|c|r|}
\hline \multicolumn{1}{|c|}{ Title } & \multicolumn{1}{|c|}{ Author } & Year & Citations \\
\hline Introduction to Physical Oceanography & $\begin{array}{l}\text { Robert H. } \\
\text { Stewart }\end{array}$ & 2008 & 93 \\
\hline Physical Geology & Steven Earle & 2015 & 14 \\
\hline Tectonics - Recent Advances & $\begin{array}{l}\text { Evgenii } \\
\text { Sharkov }\end{array}$ & 2012 & 6 \\
\hline Astronomy & $\begin{array}{l}\text { Andrew Fraknoi } \\
\text { et al. }\end{array}$ & 2016 & 4 \\
\hline Geohazards Caused by Human Activity & Arvin Farid & 2016 & 3 \\
\hline Tectonics & $\begin{array}{l}\text { Damien } \\
\text { Closson }\end{array}$ & 2011 & 3 \\
\hline $\begin{array}{l}\text { Structure and Interpretation of } \\
\text { Computer Programs }\end{array}$ & Harold Abelson & 1985 & 3 \\
\hline Linear Algebra with Applications & $\begin{array}{l}\text { W. Keith } \\
\text { Nicholson }\end{array}$ & 1995 & 2 \\
\hline Integrated Groundwater Management & $\begin{array}{l}\text { Jean-Danieli } \\
\text { Rinaudo }\end{array}$ & 2016 & 2012 \\
\hline $\begin{array}{l}\text { Poisson Noise Removal in Spherical } \\
\text { Multichannel Images: Applications to } \\
\text { Fermi Data }\end{array}$ & Seth Digel & & 3 \\
\hline
\end{tabular}

\section{Table 1: Top OER in Earth Sciences (adapted from Opensyllabus.org)}

Authors and instructors have many choices when creating OER, but future use and reuse can be limited by the initial choice of platform, hosting site or publishing software. Several platforms or hosting sites were represented in the sample, from publisher websites like Springer and the Mineralogical Society of America to products that bridge hosting and publishing needs such as Openstax, Pressbooks and Jupyter Book. It can be difficult to decouple the choice of platform, host and software as many of these components are connected. For example, some OER were created in Pressbooks, but hosted through a platform like Lumen. Some universities maintain their own local instances of Pressbooks, or other sites or repositories that serve out standalone PDFs, texts created in WordPress, or PDFs generated from LaTeX software. Our sample's selection of products is listed in Figure 1. We use "host" to encompass a hosting website or platform, i.e., where the OER lives; and "digital format" to define the resulting content type and/or file format of the authored work. 


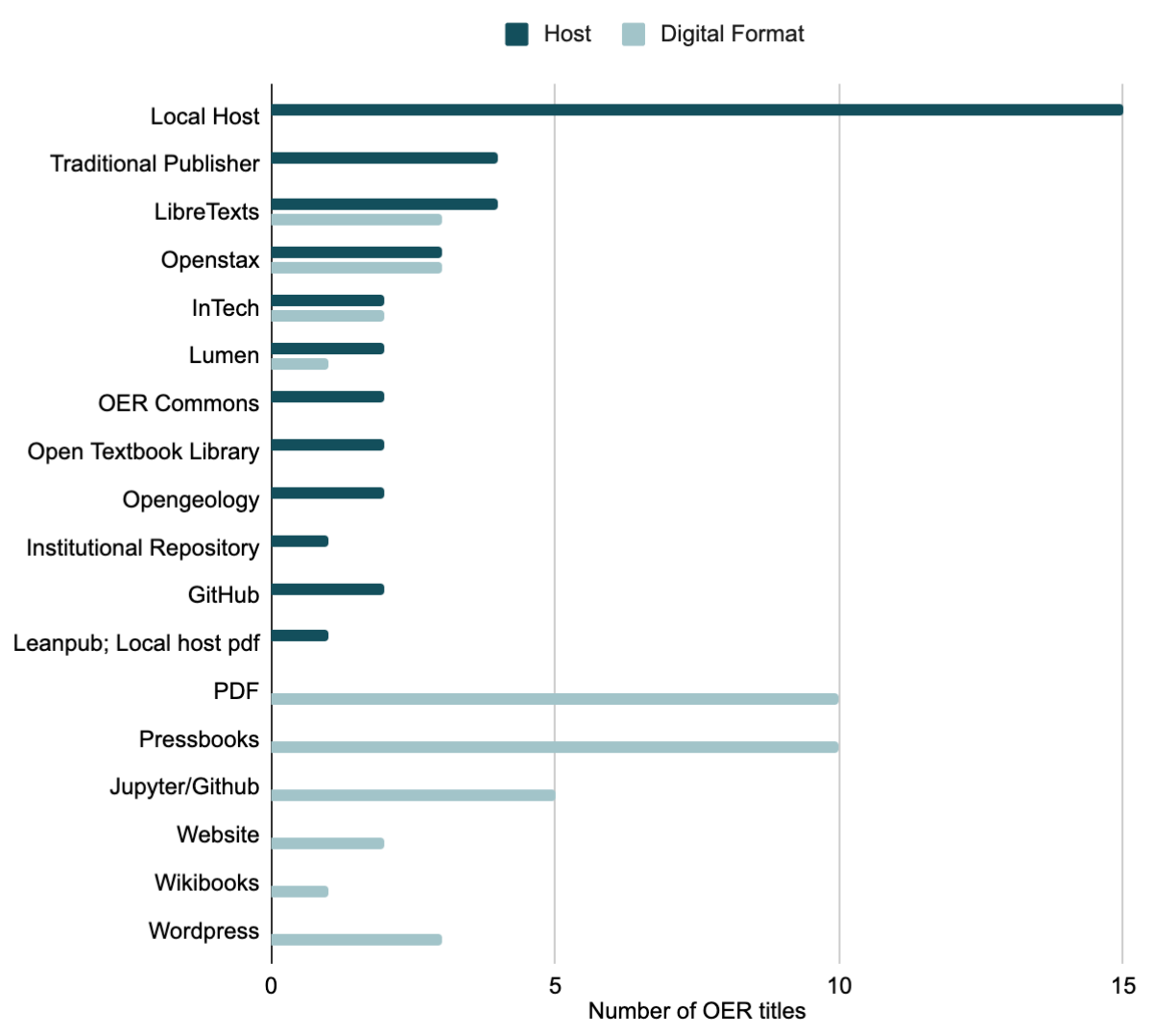

Figure 1: Geoscience OER Titles by Host and Digital Format

In some cases the same service might provide both hosting and publishing software, but the most common scenarios involved the use of the Pressbooks software via a locally hosted instance, or open PDFs hosted in a local repository or website. The other publishing options fall into approximately four categories that determine the level of interaction a user can expect, as well as the ease of reuse on the part of an instructor:

- Texts that are freely available, but essentially static PDFs free to download;

- Web-hosted content that can be viewed online and might incorporate minimal interactive content through software like Pressbooks; these might also have a download option

- Modular content that is readily available to drag/drop and mix and match (ex. LibreText);

- Dynamic content requires the most technical skill but also allows for the most dynamic interaction for computational topics (ex. Jupyter Books whose content is hosted in GitHub). GitHub-hosted books might require a steeper learning curve, but allow content to be more interactive, including advanced computation and mathematics.

Many of the OER studied are incomplete, or have not had recent updates. Many could also be improved by peer review and copy editing. Several are described as the result of institutional or nationally (US and Canadian examples) funded grants and suggest that these are big efforts undertaken on small budgets. 
Without seeing the backend of these OER, it is difficult to determine which choices are limited by time or funding, and which by the platforms themselves. One benefit of OER (to the instructor) is the ability to reuse and repurpose content. Several OER list statements that encourage reuse and ask adopters to share their experiences, make suggestions or edits, or connect with the original authors. One author stated, "Are you using this book in a class, workshop, or for any other reason? We would love to know! Fill out this quick form to help us track how and where our textbooks are being used!"

(https://www.oercommons.org/courses/introduction-to-oceanography) Another author noted "I wrote this book with a strong emphasis on reproducibility of the content. For example, most of the figures in the notes are generated interactively, often using data pulled from public servers. This means that readers are able to reproduce all the results and use the code as starting points for their own investigations." (https://brian-rose.github.io/ClimateLaboratoryBook/how-to.html) One OER in our sample was created by editing and reusing the content of another text in our sample (Physical Geology, First University of Saskatchewan Edition, is the product of several years' work iteratively adapting Steven Earle's original Physical Geology textbook.).

After evaluating the 40 titles in our sample, it is clear that OER, particularly in the geosciences, are in flux. Titles that conveyed quality content with clear attributions and citation, accessible design, and clear licensing were rare. We also looked for sustainability (DOI or persistent link), discoverability (had the title been cataloged), usage or download statistics, and clear versioning information. We offer the guidelines below for OER authors and publishers to apply to their works to increase their discoverability and preservation.

\section{Proposed Guidelines}

In 2018, the Geoscience Information Society revised its "Guidelines for Authors, Editors, and Publishers of Geologic Field Trip Guidebooks" (GSIS, 2018). These guidelines focus largely on standardizing field guides as a form of gray literature, for future findability and preservation, but offer a useful earlier starting point for OER as well, particularly "Additional guidelines for guidebooks issued in digital format" (GSIS, 2018, p. 3). The recommendations for digital formats included:

- Printing/viewing - ability to print and view in multiple formats

- Platform - functional on multiple platforms independent of operating system or device

- Searchability - full text searchable

- Accessibility - follows web content accessibility guidelines, including ALT tags for images, etc.

- Graphics standards - comply with relevant standards for graphics, videos and animations

- Unique permanent identifier - links to a persistent unique identifier

- Archival copy - permanent versioned copy deposited in archival repository.

Not all of these are as relevant to OER as they are to field trip guidebooks, but several carry forward in our suggestions below. 


\section{Discussion}

We offer Proposed Guidelines for OER in the Geosciences in Table 2 (p. 14-15), and available at (https://doi.org/10.5281/zenodo.5542306) to provide a starting point or baseline for developing OER in the geosciences. The guidelines are organized into eight themes, depicted in the schematic below (Figure 2). Many of the components are easily met with the use of common OER platforms (inclusion of a search box, for example), but others require additional actions to make these works as broadly findable and usable as possible. The components are described in this section, and detailed with examples in the stand-alone guidelines (Table 2).

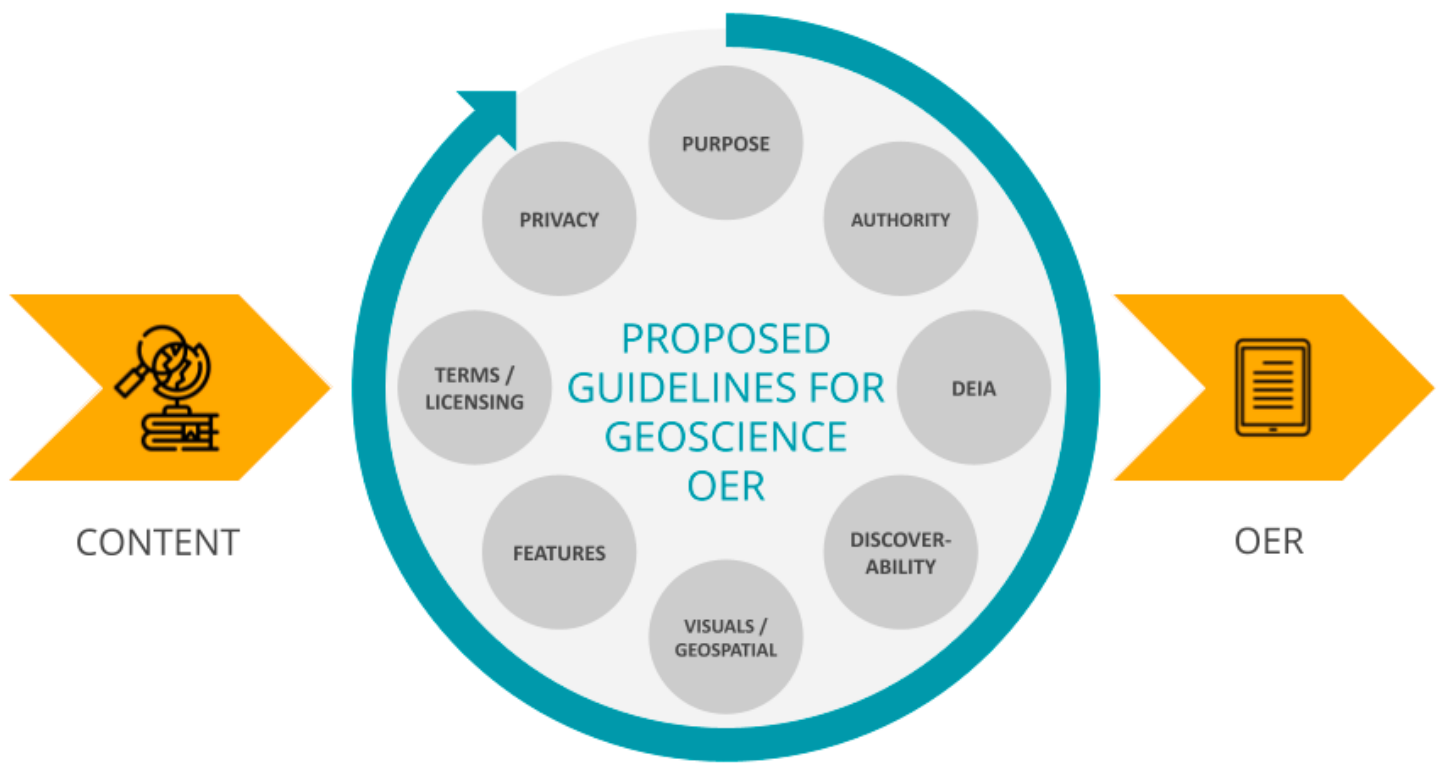

Figure 2: Schematic of Proposed Guidelines for Geoscience OER

\section{Purpose}

OER should have a clear purpose that delineates the audience for the work and connects the subject to learning or course objectives. Most OER in our sample are used for one course only, though likely for multiple sessions of a course. Having a clear purpose will aid with the broader adoption and adaptation of the work.

\section{Authority}

Authority covers many concepts that confirm the legitimacy, quality, accuracy, and relevance of the work. Most works include an author, but the addition of affiliation confirms both the identity of the author(s) and their expertise in the subject. We also support the use of clear citations and 
Table 2. Proposed Guidelines for Geoscience Open Educational Resources (OER) https://doi.org/10.5281/zenodo.5542306

\begin{tabular}{|c|c|c|}
\hline THEME & COMPONENTS & GEOSCIENCE EXAMPLES \& RECOMMENDATIONS \\
\hline \multirow[t]{2}{*}{ Purpose } & Define intended audience & $\begin{array}{l}\text { "This book is an introduction to climate science for undergraduate students of both science and non-science majors } \\
\text { and for everybody interested in the topic." https://open.oregonstate.education/climatechange/front-matter/preface/ } \\
\text { "The author designed this book for students and professionals who want to understand and apply basic } \\
\text { meteorological concepts, but who don't need to derive equations." } \\
\text { https://open.bccampus.ca/browse-our-collection/find-open-textbooks/?subject=Meteorology }\end{array}$ \\
\hline & $\begin{array}{l}\text { Match content with course learning objectives } \\
\text { and outcomes }\end{array}$ & $\begin{array}{l}\text { "The diagram below maps the modules from the book (Book Chapters) to their use in the course through a typical } \\
\text { semester using color-coded arrows." https://viva.pressbooks.pub/petrologv/chapter/1-2-how-is-this-book-organized/ }\end{array}$ \\
\hline \multirow{4}{*}{ Authority } & Make authorship and affiliations clear & $\begin{array}{l}\text { Rain or shine: an introduction to Soil Physical Properties and Processes / } \\
\text { Tyson E. Ochsner, Oklahoma State University } \\
\text { https://open.library.okstate.edu/rainorshine/front-matter/cover-page/ }\end{array}$ \\
\hline & $\begin{array}{l}\text { Include citations and references to text and } \\
\text { images as needed }\end{array}$ & $\begin{array}{l}\text { Figure 7.1 Lava lake of Mount Nyiragongo, a volcano in the Democratic Republic of Congo. Igneous rocks form when } \\
\text { melted rock freezes. Source: Karla Panchuk (2018) CC BY-NC-SA 4.0. Photo by Baron Reznik (2015) CC BY-NC-SA } \\
\text { 2.0. https://openpress.usask.ca/physicalgeology/part/chapter-7-igneous-rocks-3rd-ed/ }\end{array}$ \\
\hline & $\begin{array}{l}\text { Quality of explanations of concepts; } \\
\text { Peer Review or equivalent }\end{array}$ & $\begin{array}{l}\text { Traditional textbooks may include endorsements by instructors. Our environmental scan does not include any } \\
\text { examples for OER but we support resource open review by subject experts to assess quality and flow of information. }\end{array}$ \\
\hline & Versioning/Currency & $\begin{array}{l}\text { This page provides a record of edits and changes made to this book since its initial publication in the B.C. Open } \\
\text { Textbook Collection. https://opentextbc.ca/physicalgeology2ed/back-matter/versioning-history/ } \\
\text { Physical Geology, Versioning History: https://openpress.usask.ca/physicalgeology/front-matter/versioning-history/ }\end{array}$ \\
\hline \multirow{5}{*}{$\begin{array}{l}\text { Diversity, Equity, } \\
\text { Inclusion, } \\
\text { Accessibility }\end{array}$} & Diverse representation of gender and race & $\begin{array}{l}\text { "Following the Washington Post's gender-inclusive style guide, the singular they is intentionally used throughout the } \\
\text { text." https://worldgeo.pressbooks.com/front-matter/introduction/ } \\
\text { Include diverse representations and depictions of scientists in highlighted images. }\end{array}$ \\
\hline & $\begin{array}{l}\text { Confirm that OER meets accessibility } \\
\text { guidelines }\end{array}$ & $\begin{array}{l}\text { "Accessible files with optical character recognition (OCR) and auto-tagging provided by the Center for Inclusive } \\
\text { Design and Innovation." https://oer.galileo.usg.edu/geo-textbooks/1/ }\end{array}$ \\
\hline & Downloadable/available offline & Risk Analysis in the Earth Sciences - https://leanpub.com/raes \\
\hline & Language/Translation & Provide non-English translation options \\
\hline & Provides virtual field experience & https://opengeologv.org/historicalgeologv/case-studies/coast-ranges-accretionary-wedge/ \\
\hline \multirow[t]{2}{*}{ Discoverability } & $\begin{array}{l}\text { Include standard bibliographic metadata: } \\
\text { Title } \\
\text { Author(s) } \\
\text { Publication Date } \\
\text { DOI and/or stable URL }\end{array}$ & $\begin{array}{l}\text { Introduction to Earth Data Science } \\
\text { Leah Wasser and Jenny Palomino } \\
\text { Updated: June } 7,2021 \\
\text { https://doi.org/10.5281/zenodo.3382162 }\end{array}$ \\
\hline & $\begin{array}{l}\text { Have your work cataloged by your campus } \\
\text { library }\end{array}$ & https://www.worldcat.org/title/geological-st \\
\hline Features & $\begin{array}{l}\text { Interactivity - homework assignments, } \\
\text { quizzes, interactive simulations and } \\
\text { visualizations, in-site grading options. }\end{array}$ & $\begin{array}{l}\text { The Climate Laboratory: A Hands-on Approach to Climate Physics and Climate Modeling } \\
\text { Includes interactive code and assignments via Jupyter Notebook/Binder. Multiple example pages including: } \\
\text { https://brian-rose.github.io/ClimateLaboratoryBook/courseware/zero-dim-ebm.html }\end{array}$ \\
\hline
\end{tabular}


This paper is a non-peer reviewed preprint submitted to EarthArXiv.

\begin{tabular}{|c|c|c|}
\hline & Search box & $\begin{array}{l}\text { https://openstax.org/books/astronomy/pages/1-introduction } \\
\text { https://openpress.usask.ca/physicalgeology/ }\end{array}$ \\
\hline & Local focus & $\begin{array}{l}\text { Hawaiian Focus Box, Chapter } 5 \text { Example: } \\
\text { http://pressbooks-dev.oer.hawaii.edu/atmo/chapter/chapter-5-atmospheric-stability/ }\end{array}$ \\
\hline & Mix/Match & $\begin{array}{l}\text { "Adapted from Physical Geology written by Steven Earle for the BCcampus Open Textbook Project" } \\
\text { https://openpress.usask.ca/physicalgeologv/ } \\
\text { "I would like to extend my thanks to Steven Earle, whose book Physical Geology I have drawn from heavily in the } \\
\text { geological sections of this text." } \\
\text { Acknowledgements Page: https://www.oercommons.org/courses/introduction-to-oceanography/view\# }\end{array}$ \\
\hline & Comments/Suggestions & $\begin{array}{l}\text { "Are you using this book in a class, workshop, or for any other reason? We would love to know! Fill out this quick } \\
\text { form to help us track how and where our textbooks are being used!" } \\
\text { From preface of: https://www.oercommons.org/courses/introduction-to-oceanography/view\# }\end{array}$ \\
\hline \multirow{5}{*}{ Visuals/Geospatial } & Embed images and videos & $\begin{array}{l}\text { "Virtual Field Trip: The Northern San Andreas Fault" [embedded YouTube video] } \\
\text { https://opengeology.org/historicalgeologv/plate-tectonics }\end{array}$ \\
\hline & Tag visuals with ALT text & $\begin{array}{l}\text { "Mars photographed by the Hubble Space Telescope" https://cnx.org/contents/k8PEmDZz@10/The-Geologv-of-Mars } \\
\text { "Conceptual cross-section through the Culpeper Basin" } \\
\text { https://opengeologv.org/historicalgeologv/plate-tectonics/\#Rift basins }\end{array}$ \\
\hline & Georeference maps, images and videos & $\begin{array}{l}\text { There are not ready examples of texts that georeference media, but Introduction to Earth and Environmental Data } \\
\text { Science includes a chapter about creating maps: } \\
\text { https://earth-env-data-science.github.io/lectures/mapping cartopy.html }\end{array}$ \\
\hline & Credit reused visuals & $\begin{array}{l}\text { "Original image by Jonathan R. Hendricks. Creative Commons License. This work is licensed under a Creative } \\
\text { Commons Attribution-ShareAlike } 4.0 \text { International License. Modified by Callan Bentley." } \\
\text { https://opengeology.org/historicalgeology/geologic-time/\#Example } 2\end{array}$ \\
\hline & $\begin{array}{l}\text { Link visuals to external viewers, annotation } \\
\text { and editing tools }\end{array}$ & $\begin{array}{l}\text { "Geologic map of Pennsylvania (2nd ed.). Pennsylvania Geological Survey, Map 1, scale 1:250,000." } \\
\text { https://opengeology.org/historicalgeology/tools-of-historical-geology/geologic-maps/ } \\
\text { "Fossil specimen of the ceratite ammonoid Gymnotoceras beachi" ... } \\
\underline{\text { https://opengeology.org/historicalgeology/geologic-time/\#Biozones }}\end{array}$ \\
\hline Terms \& Licensing & $\begin{array}{l}\text { Display clear licensing and copyright } \\
\text { information; } \\
\text { Aim to allow reuse or repurposing }\end{array}$ & $\begin{array}{l}\text { "Introduction to Climate Science by Andreas Schmittner is licensed under a Creative Commons } \\
\text { Attribution-NonCommercial } 4.0 \text { International License, except where otherwise noted." } \\
\text { https://open.oregonstate.education/climatechange/front-matter/preface/ }\end{array}$ \\
\hline Privacy & $\begin{array}{l}\text { Describe approach to privacy and collecting of } \\
\text { student data; } \\
\text { Aim for transparency under the hood; use } \\
\text { non-proprietary software }\end{array}$ & $\begin{array}{l}\text { Pressbooks sets out the terms of their Privacy Policy, but different terms might apply for institutional sites: } \\
\text { https://pressbooks.com/privacy-policy/ }\end{array}$ \\
\hline
\end{tabular}

Links accessed September 28, 2021 
references in the work. This confirms the authors' rights to include the material in the case of the reuse of images and figures, but also connects the work to larger scholarly conversations through clear references in a bibliography either at the end of each chapter or at the end of the text. Under authority, we also include versioning or currency to attest to the continued relevance of the work, and outside review to certify the quality of the information presented. This may take the form of peer review prior to publication, or book reviews offering evaluation afterward.

\section{Diversity, Equity, Inclusion and Accessibility}

Under Diversity, Equity, Inclusion and Accessibility (DEIA), we include the concepts of representation, including gender and racial representation in images through the work, as well as the accessibility of the work itself. Pearson's recent guidelines (Pearson, 2021) help authors consider not only imagery included in the work, but also context and framing examples. In geoscience, these might be depictions of geologists or sensitivity concerning field sites, among other topics.

"Accessibility" in this section refers both to compliance with general web content accessibility guidelines and to the potential for OER in geoscience to enable all readers to visit geological field locations through virtual experiences - including sites that for physical, legal, or ethical reasons may be unreachable in person. There are many resources available to create compliant OER both online (example: https://opentextbc.ca/accessibilitytoolkit/) and locally through campus student disability offices (example:

https://dsp.berkeley.edu/faculty/resources-faculty/creating-accessible-content).

\section{Discoverability}

Discoverability refers to the ability to locate and identify a given work. While Google is always a starting point, it is helpful to be able to locate geoscience oriented OER in databases relevant to the field. Basic metadata is required to add OER to library catalogs. Seventeen works in our sample were found in WorldCat, a global union catalog relied upon by most academic libraries.

\section{Features}

Features might be considered from the perspective of the instructor who might evaluate a resource for its ability to support teaching with add-ons like embedded quizzes, problem sets and grading. In this vein, instructors might prefer resources that offer easy reuse to limit preparation time. On the other hand, evaluating the resource with the lens of student success might support features like visualizations, simulations, virtual field experiences or other active learning exercises.

\section{Visuals/Geospatial}

Geoscience OER hold the potential to incorporate inspiring and relevant visual information. Due to the spatial nature of the field, including geospatial metadata is important, but relatively uncommon at this point. 


\section{Terms \& Licensing}

Including clear terms and licensing should not be onerous, and simplifies repurposing and reuse of materials. (Example: reuse of Earle's Physical Geology by Panchuk). Licensing options can be found at: https://creativecommons.org/about/cclicenses/

\section{Privacy}

Increasing concerns about student privacy, both in terms of sharing personal data and required online participation, should be considered as part of OER creation and adoption. For example, Introduction to Climate Change from Oregon State University, includes download stats and locations in a data dashboard (https://datastudio.google.com/u/0/reporting/57774d44c-b487-44cd-adb8-1e861582b090/page/Q $\underline{Z N d B})$. The granularity of such download statistics as well as the requirements to maintain student privacy where interactive elements are involved should both be predetermined.

\section{Aspirational geoscience elements}

We have highlighted geoscience OER that showcase the proposed Guidelines (Table 2), but there is an abundance of geoscience tools, content, and material available online that do not necessarily fall under the OER label. Looking ahead, geoscience as a discipline has the opportunity to use software and other content to create engaging immersive experiences that may be incorporated into future OER.

1. Visualization products could be integrated into OER to display stratigraphic or other spatial information. Some examples include stratigraphic columns (https://stratigraphy.org/timescale/), and tools like Macrostrat (https://macrostrat.org/) and the National Geologic Map Database (https://ngmdb.usgs.gov)

\section{Virtual field experiences}

Klippel et al. (2019), and Gregory et al. (2021) report on the value of and advantages of immersive virtual field trip experiences. Apart from a reaction to the current conditions related to COVID-19, virtual experiences offer a global reach with limited monetary outlay and a reduced carbon footprint. Inaccessible sites due to weather, cost, time and physical accessibility, can be made accessible through this medium. It is possible to include virtual site information, aerial photographs, and rendered outcrops. There is promise in the integration of apps like Rockd (https://rockd.org) and other cartographic tools. One example, Svalbox (https://www.svalbox.no/) provides a suite of tools to visualize and experience the geologic setting of Svalbard from a remote location.

\section{Virtual samples}

Similarly, virtual samples related to 3-D Models, within virtual and augmented reality, hold promise to mimic live sample collection. Links to view, sketch and annotate samples provide further opportunities for interaction.

4. Georeferencing and improved geospatial metadata

GIS software and other mapping tools could fill an entire study, but for the purposes of this proposal, we recommend that included maps, images and videos be georeferenced 
and geospatial metadata be included to improve discoverability of content in place-based searching.

\section{Conclusion}

Open Educational Resources in the geosciences have potential to increase access to information, improve learner engagement, and reduce expenses for readers. The future utility of geoscience OER may depend on the amount of resources allocated to create and maintain the work. To date, many available OER options are created with the intention of meeting the needs of a unique course in a specific institutional setting. The geoscience-relevant OER reviewed for this project make limited use of interactive or geo-specific technical features. There is a significant cost involved in the integration and maintenance of such features. Much of the initial work to create an OER is funded by short-term local grants that boost innovation, but limit updates and broad adoption. These conditions tend to favor the creation of introductory textbooks, and works that do not require significant labor for the creation or refinement of images, problem sets, or other integrations.

Regardless of the future state of geoscience OER, adherence to standards allows authors, instructors, and libraries to more efficiently evaluate available OER for immediate use, and ease the workload associated with the creation of OER. Authors may benefit from standards designed to increase the discoverability and reach of geoscience OER. The themes offered in Table 2 - Purpose, Authority, Discoverability, DEIA, Features, Visuals/Geospatial, Terms and Licensing, and Privacy - will guide authors as they build and promote their works, potentially beyond single semester courses.

To facilitate discovery, instructor uptake, and use of OER, libraries should establish:

- Guidance for instructor discovery of OER (guidance determining pedagogical need, finding and evaluating appropriate OER and free resources)

- Paths for collecting OER (license and permissions review, establish criteria for acquisition preferences - for example, favoring DRM-free content and/or locally created OER)

- Paths for patron discovery of OER in library environments (criteria for adding OER and other free resources to catalog, metadata requirements, establish preferred formats and/or platforms)

- Preservation plan (dedicated hosting/server space, deposit of locally created content in institutional repository, periodic review, weeding policies, check-in with faculty)

- Community of practice (build network of instructors adopting OER, OER providers, consortia, academic institutions for learning and sharing)

This work was an initial exploration of the availability of OER in geoscience with recommendations for their continued creation and adoption. Future work might include a survey of OER creators and adopters to explore their experiences and assess future needs. Uptake and creation of OER is linked to the reward structures for adopters of OER by instructors in higher education. Open questions remain regarding how credit is given for OER as pedagogical or research objects, whether OER help to meet tenure and promotion requirements, and what 
roadblocks exist for creating, maintaining and sustaining quality OER. Finally, geoscience OER offer the potential for better integration and thus use of data sets and technical features specific to the discipline. It is worth investigating both the true cost and the sustainability of OER creation that would enable this type of integration. We hope to answer these questions in future studies, but also send them out into the community to extend the conversation.

\section{References}

Allen, G., Guzman-Alvarez, A., Smith, A., Gamage, A., Molinaro, M., \& Larsen, D. S. (2015). Evaluating the effectiveness of the open-access ChemWiki resource as a replacement for traditional general chemistry textbooks. Chemistry Education Research and Practice, 16(4), 939-948. https://doi.org/10.1039/C5RP00084J

Allen, I. E., \& Seaman, J. (2012). Growing the Curriculum: Open Education Resources in U.S. Higher Education, 2012. Babson Survey Research Group. https://www.bayviewanalytics.com/oer.html

Allen, I. E., \& Seaman, J. (2014). Opening the Curriculum: Open Educational Resources in U.S. Higher Education, 2014. Babson Survey Research Group. https://www.bayviewanalytics.com/reports/openingthecurriculum2014.pdf

Allen, N. (2018, October 12). \$1 Billion in Savings through Open Educational Resources. SPARC News.

https://sparcopen.org/news/2018/1-billion-in-savings-through-open-educational-resource s/

Arnaud, C. (2019). Open-access chemistry textbooks gain popularity. Chemical \& Engineering News.

https://cen.acs.org/education/undergraduate-education/Open-access-chemistry-textbook s-gain/97/i11

Basken, P. (2020, May 5). US textbook publisher merger collapses, pleasing colleges. Times Higher Education (THE).

https://www.timeshighereducation.com/news/us-textbook-publisher-merger-collapses-ple asing-colleges

Bentley, C., Jaye, S. A., Kohrs, R. H., \& Layou, K. M. (2020, March 22). Historical Geology for the 21st Century: A Free, Open-Access Text "book." Joint 69th Annual Southeastern / 55th Annual Northeastern Section Meeting - 2020. https://gsa.confex.com/gsa/2020SE/webprogram/Paper344127.html

Blicher, H., Essmiller, K., \& Santiago, A. (2021, January 11). Open Educational Resources and Affordability: A Three-Part Webcast Series. https://www.ala.org/acrl/onlinelearning/oerwebcastseries

Bliss, T. J., Robinson, T., Hilton, J., \& Wiley, D. (2013). An OER COUP: College Teacher and Student Perceptions of Open Educational Resources. Journal of Interactive Media in Education, 2013(1), Art. 4. https://doi.org/10.5334/2013-04

Brady, J. B. (2020, October 28). An Online Textbook with Interactive Tools Designed to Help Undergraduate Students Learn Igneous And Metamorphic Petrology. GSA 2020 Connects Online. https://gsa.confex.com/gsa/2020AM/webprogram/Paper355219.html

Bush, P., \& Mattox, S. (2020). Decadal review: How gender and race of geoscientists are 
portrayed in physical geology textbooks. Journal of Geoscience Education, 68(1), 2-7. https://doi.org/10.1080/10899995.2019.1621715

Call for Members-NEW LIBER Working Group on Educational Resources. (2021, April 22). LIBER Europe.

https://libereurope.eu/article/call-for-members-new-liber-working-group-on-educational-re sources/

Camera, L. (2019). Textbook Giant Pearson Makes Major Shift Away From Print to Digital | Education News | US News.

https://www.usnews.com/news/education-news/articles/2019-07-15/textbook-giant-pears on-makes-major-shift-away-from-print-to-digital

Christman, R., Aronoff, S., Burmester, R., Babcock, S., Engebretson, D., Schwartz, M., Talbot, J., \& Wodzicki, A. (1985). Evaluations of Some Introductory Geology Textbooks. Journal of Geological Education, 33(3), 188-191. https://doi.org/10.5408/0022-1368-33.3.188

Dhanarajan, G., \& Porter, D. (2013). Open educational resources: An Asian perspective. Commonwealth of Learning and OER Asia.

Farrow, R., Pitt, R., \& Weller, M. (2020). Open Textbooks as an innovation route for open science pedagogy. Education for Information, 36(3), 227-245. https://doi.org/10.3233/EFI-190260

Fischer, L., Hilton, J., Robinson, T. J., \& Wiley, D. A. (2015). A multi-institutional study of the impact of open textbook adoption on the learning outcomes of post-secondary students. Journal of Computing in Higher Education, 27(3), 159-172. https://doi.org/10.1007/s12528-015-9101-x

Fisher, M. R. (2018). Evaluation of Cost Savings and Perceptions of an Open Textbook in a Community College Science Course. The American Biology Teacher, 80(6), 410-415. https://doi.org/10.1525/abt.2018.80.6.410

Geoscience Information Society. (2018). Guidelines for Authors, Editors, and Publishers of Geologic Field Trip Guidebooks. http://www.geoinfo.org/wp-content/uploads/2019/02/guidebook-guidelines.pdf

Gilbert, L. A., Gross, D. S., \& Kreutz, K. J. (2019). Developing undergraduate students' systems thinking skills with an InTeGrate module. Journal of Geoscience Education, 67(1), 34-49. https://doi.org/10.1080/10899995.2018.1529469

Gold, A. U., Ledley, T. S., Buhr, S. M., Fox, S., McCaffrey, M., Niepold, F., Manduca, C., \& Lynds, S. E. (2012). Peer-Review of Digital Educational Resources-A Rigorous Review Process Developed by the Climate Literacy and Energy Awareness Network (CLEAN). Journal of Geoscience Education, 60(4), 295-308. https://doi.org/10.5408/12-324.1

Gregory, D. D., Tomes, H. E., Panasiuk, S. L., \& Andersen, A. J. (2021). Building an online field course using digital and physical tools including VR field sites and virtual core logging. Journal of Geoscience Education, 0(0), 1-16. https://doi.org/10.1080/10899995.2021.1946361

Hendricks, J. R. (2018, November 7). The Digital Encyclopedia of Ancient Life (DEAL): An Open Access Paleontology Textbook. GSA Annual Meeting in Indianapolis, Indiana, USA 2018. https://gsa.confex.com/gsa/2018AM/webprogram/Paper318607.html

Santos-Hermosa, G., Estupinyà, E., Nonó-Rius, B., Paris-Folch, L., \& Prats-Prat, J. (2020). Open educational resources (OER) in the Spanish universities. Profesional de la 
Información, 29(6).

Hilton, J. (2016). Open educational resources and college textbook choices: A review of research on efficacy and perceptions. Educational Technology Research and Development, 64(4), 573-590. https://doi.org/10.1007/s11423-016-9434-9

IFLA. (2019). Open Educational Resources and Libraries. https://www.ifla.org/files/assets/clm/news/oer_ifla_brief.pdf

IFLA -- IFLA Responds to Consultation on Open Educational Resources. (2018, June 4). https://www.ifla.org/node/52095

Jhangiani, R. S., \& Jhangiani, S. (2017). Investigating the Perceptions, Use, and Impact of Open Textbooks: A survey of Post-Secondary Students in British Columbia. The International Review of Research in Open and Distributed Learning, 18(4). https://doi.org/10.19173/irrodl.v18i4.3012

Johnson, C., Inkenbrandt, P. C., Affolter, M., Mosher, C., \& Mosher, C. (2017). Opengeology.org: A Free Textbook for College-Level Introductory Geology Classes. 307489. https://doi.org/10.1130/abs/2017AM-307489

Johnson, E. A., Liu, J. C., Mao, J., \& Kansal, R. (2018). Accessibility and User Experience in Design and Development of an Open Access Analytical Methods in Geosciences (AMiGEO) Textbook. AGU Fall Meeting Abstracts, 51. http://adsabs.harvard.edu/abs/2018AGUFMED51/0736J

Jung, I., Sasaki, T., \& Latchem, C. (2016). A framework for assessing fitness for purpose in open educational resources. International Journal of Educational Technology in Higher Education, 13(1), 3. https://doi.org/10.1186/s41239-016-0002-5

Karaganis, J. (2020, October 6). How Much Traction do Open Access / Open Educational Resources have in the Classroom? The Open Syllabus Project. https://blog.opensyllabus.org/how-much-traction-do-open-access-open-educational-reso urces-have-in-the-classroom/

Karamperidou, C., Nugent, A. D., \& Small Griswold, J. D. (2019). Creating and Using OER materials in an Intro-level Atmospheric Science Class. AGU Fall Meeting Abstracts, 12. http://adsabs.harvard.edu/abs/2019AGUFMED12A..08K

Kastens, K. (2005). The DLESE Community Review System: Gathering, Aggregating, and Disseminating User Feedback about the Effectiveness of Web-based Educational Resources. Journal of Geoscience Education, 53(1), 37-43. https://doi.org/10.5408/1089-9995-53.1.37

Klippel, A., Zhao, J., Jackson, K. L., La Femina, P., Stubbs, C., Wetzel, R., Blair, J., Wallgrün, J. O., \& Oprean, D. (2019). Transforming Earth Science Education Through Immersive Experiences: Delivering on a Long Held Promise. Journal of Educational Computing Research, 57(7), 1745-1771. https://doi.org/10.1177/0735633119854025

Kobluk, D. R. (1993). An Electronic Textbook and Its Use in a Historical Geology Course. Journal of Geological Education, 41(5), 420-424. https://doi.org/10.5408/0022-1368-41.5.420

Koenig, R. (2019, October 24). How a University Took on the Textbook Industry-EdSurge News. EdSurge. https://www.edsurge.com/news/2019-10-24-how-a-university-took-on-the-textbook-indust ry 
Kortz, K. M., Grenga, A. M., \& Smay, J. J. (2017). Establishing and Applying Literature-Based Criteria for Effective Communication of Science to Novices Via Introductory Geology Textbooks. Journal of Geoscience Education, 65(1), 48-59. https://doi.org/10.5408/16-205.1

Kristof, K. (2018). What's behind the soaring cost of college textbooks. https://www.cbsnews.com/news/whats-behind-the-soaring-cost-of-college-textbooks/

Liu, J. C., Johnson, E. A., \& Mao, J. (2021). Interdisciplinary Development of Geoscience OER: Formative Evaluation and Project Management for Instructional Design. In B. Hokanson, M. Exter, A. Grincewicz, M. Schmidt, \& A. A. Tawfik (Eds.), Intersections Across Disciplines: Interdisciplinarity and learning (pp. 209-223). Springer International Publishing. https://doi.org/10.1007/978-3-030-53875-0_17

Marlino, M., Sumner, T., Fulker, D., Manduca, C., \& Mogk, D. (2001). The digital library for earth system education: Building community, building the library. Communications of the ACM, 44(5), 80-81. https://doi.org/10.1145/374308.374356

Mathew, S., \& Kashyap, U. (2019). Impact of OER Materials on Students' Academic Performance in Undergraduate Astronomy Course. Journal of STEM Education: Innovations and Research, 20(1). https://www.jstem.org/jstem/index.php/JSTEM/article/view/2369

McKenzie, L. (2021, February 26). Tackling racism in textbook publishing. https://www.insidehighered.com/news/2021/02/26/publisher-pearson-tries-tackle-systemi c-racism-higher-ed

McNeal, K. S., Libarkin, J. C., Ledley, T. S., Bardar, E., Haddad, N., Ellins, K., \& Dutta, S. (2014). The Role of Research in Online Curriculum Development: The Case of EarthLabs Climate Change and Earth System Modules. Journal of Geoscience Education, 62(4), 560-577. https://doi.org/10.5408/13-060.1

McNeal, K. S., Libarkin, J. C., Ledley, T. S., \& Ellins, K. K. (2020). EarthLabs: A Model for Supporting Undergraduate Student Inquiry About Change over Time and Space. In J. J. Mintzes \& E. M. Walter (Eds.), Active Learning in College Science: The Case for Evidence-Based Practice (pp. 683-696). Springer International Publishing. https://doi.org/10.1007/978-3-030-33600-4_42

Mengason, M. J. (2020). Educational Resources for Early Inclusion of Analytical Techniques in Undergraduate Education. AGU - AGU Fall Meeting 2020.

https://agu.confex.com/agu/fm20/meetingapp.cgi/Paper/773278

Musser, L. R. (2017). Open Educational Resources and Affordable Instructional Resources Can They Promote Retention and Diversity? 291362. https://doi.org/10.1130/abs/2017NE-291362

OECD. (2007). Giving Knowledge for Free: The Emergence of Open Educational Resources. OECD. https://doi.org/10.1787/9789264032125-en

Omta, A. W., \& Larsen, D. (2018). The Geoscience LibreTexts library: An interactive learning platform for instructors and students. AGU Fall Meeting Abstracts, 51. http://adsabs.harvard.edu/abs/2018AGUFMED51I07350

Open Education-OpenEdu Framework. (2016, May 17). EU Science Hub - European Commission. https://ec.europa.eu/jrc/en/open-education

Open Education Group. (n.d.). The COUP Framework - Open Education Group. Retrieved April 
29, 2021, from https://openedgroup.org/coup

Palmiotto, A., \& Swift, S. (2019, August 29). Our commitment to diversity, equity, and inclusion in OpenStax textbooks.

https://openstax.org/blog/our-commitment-diversity-equity-and-inclusion-openstax-textbooks

Pearson Employee Resource Groups. (2021). Pearson Race \& Ethnicity, Diversity, Equity and Inclusion Guidelines. Retrieved September 14, 2021, from

https://www.pearson.com/content/dam/one-dot-com/one-dot-com/global/Files/news/DD0 2583PRIME-PearsonRaceEthnicityEquityDiversityandInclusionGuidelines002.pdf

Pitt, R. (2015). Mainstreaming Open Textbooks: Educator Perspectives on the Impact of OpenStax College open textbooks. The International Review of Research in Open and Distributed Learning, 16(4). https://doi.org/10.19173/irrodl.v16i4.2381

Pitts, A., \& Bentley, C. (2015). A Digital Field Guide: Using Gigapixel Imagery and Google Earth as Tools to Create Digital Field Guides and Virtual Field Experiences in Geology (2015 GSA Annual Meeting in Baltimore, Maryland, USA (1-4 November 2015)). https://gsa.confex.com/gsa/2015AM/webprogram/Paper267423.html

Recommendation on Open Educational Resources (OER). (n.d.). Retrieved September 9, 2021, from

http://portal.unesco.org/en/ev.php-URL_ID=49556\&URL_DO=DO_TOPIC\&URL_SECTI $\mathrm{ON}=201 . \mathrm{html}$

Robinson, T. J., Fischer, L., Wiley, D., \& Hilton, J. (2014). The Impact of Open Textbooks on Secondary Science Learning Outcomes. Educational Researcher, 43(7), 341-351. https://doi.org/10.3102/0013189X14550275

Rose, B. (2018). CLIMLAB: A Python toolkit for interactive, process-oriented climate modeling. Journal of Open Source Software, 3(24), 659. https://doi.org/10.21105/joss.00659

Rose, B. E. J. (2019). Interactive Climate Modeling and Reproducible Workflows in the Classroom. AGU Fall Meeting Abstracts, 52. http://adsabs.harvard.edu/abs/2019AGUFMED52A..07R

Sansom, R. L., Clinton-Lisell, V., \& Fischer, L. (2021). Let Students Choose: Examining the Impact of Open Educational Resources on Performance in General Chemistry. Journal of Chemical Education, 98(3), 745-755. https://doi.org/10.1021/acs.jchemed.0c00595

Seaman, J. E., \& Seaman, J. (2020). Digital Texts in the Time of COVID: Educational Resources in U.S. Higher Education, 2020. Bay View Analytics. https://www.bayviewanalytics.com/oer.html

Smith, D. H., Hao, Q., Hundhausen, C. D., Jagodzinski, F., Myers-Dean, J., \& Jaeger, K. (2021). Towards Modeling Student Engagement with Interactive Computing Textbooks: An Empirical Study. In Proceedings of the 52nd ACM Technical Symposium on Computer Science Education (pp. 914-920). Association for Computing Machinery. https://doi.org/10.1145/3408877.3432361

The project begins! - Australian Open Textbooks as Social Justice. (2019, November 19). Australian Open Textbook Project. https://australianopentextbooks.edu.au/2019/11/19/the-project-begins/

Wasser, L. A., Herwehe, L., \& Palomino, J. (2019). Democratizing Access to Earth Data Science Skills Using Blended Online and In-Person Approaches and Open Education. AGU Fall Meeting Abstracts, 13. http://adsabs.harvard.edu/abs/2019AGUFMED13D0905W 